Vol. 14 (2005): 236-249.

\title{
Vertical market integration and competition: the meat sector in Slovenia
}

\author{
Štefan Bojnec \\ University of Primorska, Faculty of Management, Cankarjeva 5, 6000 Koper, Slovenia, \\ e-mail: stefan.bojnec@fm-kp.si \\ Günter Peter
}

Federal Agricultural Research Centre (FAL), Institute of Market Analysis and Agricultural Trade Policy, Bundesallee 50, 38116 Braunschweig, Germany,e-mail: guenter.peter@fal.de

\begin{abstract}
This paper presents price transmission models explaining the farm-to-retail price spread and degree of competition in the meat marketing chains during the period of economic transition in Slovenia. The meat marketing chains in Slovenia are characterised by relatively large processing and marketing margins, which are expected to decline with market deregulation and integration into the international markets. As results of the economic restructuring and policy reforms, competitive market pressures in a marketing margin determination have increased, inducing pressures for efficiency improvements in the vertical market integration from the farm to the retail stage in the Slovenian meat sector. Co-integration models are applied to estimate vertical market integration and to assess the degree of price competition in the Slovenian beef and pork marketing chains. The tested econometric models confirmed the existence of the long run market integration in the meat chain and the speed of adjustment of price changes. Farm-gate meat prices are identified as weakly exogenous, indicating the crucial role of supply side processing and marketing factors in the retail meat price determination. The results of structural tests suggest a long-run mark-up price strategy in the beef, and a competitive price strategy in the pork, chain as the outcome of policy reforms. The increased competitive market pressures are very likely to increase efficiency in the beef markets. Efficiency improvements in the Slovenian food markets are needed in the increased competitive market pressures of the enlarged European Union markets.
\end{abstract}

Key words: agricultural markets, econometric models, co-integration, competition, price strategies, Slovenia, European Union enlargement

\section{Introduction}

Previous analyses of the food processing sector in Central and Eastern European (CEE) transition countries have focused on transformation and restructuring in the agri-food chain (e.g. OECD 1998), policy- and other-induced transfers in the food chain (e.g. Ivanova et al. 1995, Swinnen 1998), the budgetary implications for agricultural 
Vol. 14 (2005): 236-249.

markets and incomes (e.g. Baldwin et al. 1997, Tangermann and Banse 2000), and the relative competitiveness of agricultural and food products in the European Union (EU) and world markets (Eiteljörge and Hartmann 1999). These subjects have been analysed during the initial stage of transition and later during the adjustment process of agriculture and the food sector in CEE transition countries towards Common Agricultural Policy (CAP) in the EU.

This study was motivated by a relatively great difference in agricultural and food prices for homogenous products across countries and years (Bojnec and Swinnen 1997, OECD 1998, 2001, European Commission 2004). In competitive markets, price differences indicate quality differences, where products with higher prices should be of higher quality than cheaper ones (Stiglitz 1987). Since agricultural and food products are regarded as relatively homogenous, price differences among countries indicate distortions which are not caused by quality differences, but might be due to potential presence of market power, inefficiencies and policy distortions. The marketing margin might be influenced by market power or inefficient food chains. With shifting the CAP from market price supports towards direct payments, agricultural and food markets are exposed to greater market competition. Market deregulation in CEE transition countries and its integration in the enlarged EU market under the increased competitive pressures likely cause adjustments in price structures. The increased competition is expected to reduce market power and force farms, food processors and marketing firms to improve efficiency in the marketing chain.

To analyse the sources of inefficiencies in protected markets it is particularly relevant to carry out empirical studies, which specifically deal with the potential presence of market power. In the previous studies (Bojnec and Swinnen 1997, OECD 1998, 2001, European Commission 2004) Slovenia was recorded as a country with the highest agricultural and food prices for homogenous products in comparison to other CEE transition countries. The objective of this study is to apply methodological approaches and empirical techniques to identify the potential presence of market power in the Slovenian meat markets by analysing price transmission in the beef and pork marketing chains. Therefore, the policy relevance of our empirical results is of broader international interest. First, the level of government support to Slovenian agriculture and to the meat producers as measured by producer subsidy equivalents (PSE) is relatively high. It accounts for more than $40 \%$ of revenue (OECD 2001, MAFF 2002). Similar to the EU-15, this is mainly achieved by market price support measures. Due to higher domestic than world food prices, efficiency in consumption was reduced, which is consistent with the negative consumer subsidy equivalents (CSE) as an indication of consumer taxation. Rather large farm-to-retail price spreads in the Slovenian meat markets are the result of distortional policy measures (Bojnec 1999), but might also be due to market power. As the Slovenian meat markets have been gradually adjusted towards accession to the EU, it is interesting to study the potential market changes and policy implications in meat markets arising from these adjustments. Second, in spite of the important policy relevance of imperfect competition to date, no study examines vertical market integration for CEE transition economies. Third, the article provides in-depth evidence on vertical market integration and on the magnitude and pattern in development of the processing and marketing margin. This study is based on the assumption that price liberalization and market deregulation will be reflected by a more competitive and efficient price transmission. We use the multivariate Johansen (1988, 1992) maximum likelihood (ML) co-integration approach to study long-run vertical price relationships at the farm and retail stages, market integration effects and degree of competition. Within this approach we test whether markets are competitive, i.e., whether industries operate with constant margins. Additionally, exogeneity tests are applied to analyse the direction of price changes (farm-to-retail or vice versa). The in-depth analysis and empirical results are relevant to the Slovenian context of transition and integration into EU as well as for comparisons and lessons learned in general. 
This paper focuses on the Slovenian beef and pork markets, of which selected key figures are presented in the following. The production structures in the primary markets for cattle and hogs in Slovenia differ in the sense that most cattle is produced by a large number of small-scale individual farms (for example, 95\% and 97\% of total cattle production in 1997 and 2000, respectively), while hog production is pursued to a certain extent also on large-scale commercial farms (39\% and 35\%, respectively, of total hog production) (Table A1 in Appendix). The number of enterprises in production, processing and preserving of meat and meat products is greater than the number of slaughterhouses for cattle and hogs (Table A2). Besides slaughterhouses for cattle and hogs, there are also three poultry slaughterhouses. There is also some degree of specialization of slaughterhouses and meat processing enterprises to utilize economies of scale. Regarding the hog sector, there were eleven registered slaughterhouses, all of them also engaged in cattle slaughtering. In comparison, there were 35 slaughterhouses for cattle. As market shares indicate, cattle slaughtering was less concentrated than hog slaughtering. In 2000, the shares of the four largest hog and cattle slaughterhouses accounted for $62 \%$ and $37 \%$, respectively, while in the case of the six largest slaughterhouses, the shares were $89 \%$ and $48 \%$, respectively. In relation to the small Slovenian population of about two million inhabitants the firm number is not an issue of special concern. Meat markets are fairly richly structured as there are often more than five firms competing in the market. Hog slaughterhouses seem to be more specialized to utilize economies of scale. ${ }^{1}$ Wholesale marketing of meat (beef and

\footnotetext{
1 In the meat processing sector, there has been an urgent need for adjustments on the developments in the implementation of EU quality and sanitary standards as part of the acquis communautaire or higher veterinary, hygiene, sanitary, environmental, grading and quality requirements. The slaughtering of cattle by households is forbidden, while slaughtering of hogs is allowed for the home consumption needs of households. According to the Slovenian meat market, balances of the slaughtering of hogs at the agricultural households, including on the large
}

pork) is largely in the hands of slaughterhouses and meat processors. They are also the main exporters and importers of cattle, hogs and meats. Retail trade in meat (beef and pork) is rather dispersed among different kinds of butchers, retail shops and supermarkets.

The next section of the article presents methods and data used focusing on the theoretical background on market integration and price competition, and the methodology and data used in the empirical analysis. Following this, we present empirical procedures and results of the estimated unit root tests, the multivariate Johansen ML co-integration results for market integration and the degree of market competition. The final section summarizes the main empirical results and draws main conclusions.

\section{Methods and data}

\section{Theoretical framework on market integra- tion and price competition}

The relationships in the meat chain are investigated by comparing retail meat prices and farm-gate prices within a linear model. The difference be-

commercial farms, was $30 \%$ in 1992 and $22 \%$ in 2000 of total domestic hog production. However, the slaughtering of hogs by the households varied by individual years. For example, it was around $31 \%$ in the period 1993-1995, $32 \%$ in 1996, 27\% in 1997 and in 1998, and 25\% in 1999. Yet, it increased in 2001 (31\%), declined in 2002 (25\%), and again increased in 2003 (33\%). These patterns over time capture a combination of economic and policy changes, including changes in slaughtering regulations. As the slaughtering of hogs on the commercial farms is rare, most of the hogs' slaughtering is by family farms or individual agricultural households. Besides agricultural households, final consumers of pork from the slaughtered hogs in the individual agricultural households are likely also their relatives, friends and tourists at tourist farms. While no exact percentage is available, most of pork produced by small-scale family farms is used for home consumption. 
Vol. 14 (2005): 236-249.

tween a retail price $\left(\mathrm{P}_{\mathrm{r}}\right)$ and a farm gate price $\left(\mathrm{P}_{\mathrm{f}}\right)$ is the processing and marketing margin $(\mathrm{M})$. The vertical price relationship can be described as:

$$
\mathrm{P}_{\mathrm{r}}=\mathrm{M}+\mathrm{P}_{\mathrm{f}} \text {. }
$$

The margin (M) can generally be seen as a linear combination of a constant absolute amount (a) and a percentage (mark-up) amount (b) of the retail price (e.g. Tomek and Robinson 1995, Jumah 2000):

$$
\mathrm{M}=\mathrm{a}+\mathrm{bP}_{\mathrm{r}},
$$

with $\mathrm{a} \geq 0$ and $0 \leq \mathrm{b}<1$.

Under perfect competition $b$ equals zero $(b=$ $0)$ and the margin is constant $(M=a)$, which denotes marginal cost. ${ }^{2}$ The difference between the product margin and the marginal cost can be interpreted as an indicator of monopolistic power. When exercising market power, the meat processors and meat traders influence margins in such a way that it will be above marginal costs by charging mark-up in an amount $0<\mathrm{b}<1$ of the retail price. By substituting equation (1) into (2) it leads to:

$$
P_{r}=a+b P_{r}+P_{f}
$$

or

$$
P_{r}=\frac{1}{1-b} a+\frac{1}{1-b} P_{f}
$$

If a market is perfectly competitive there is no percentage mark-up in the market, i.e., $b=0$, and hence only a constant absolute margin remains in equation (4):

$$
\mathrm{M}=\mathrm{a}=\mathrm{P}_{\mathrm{r}}-\mathrm{P}_{\mathrm{f}} \text {. }
$$

Equation (4) can be rewritten in the reduced form as:

$$
\operatorname{Pr}=\hat{a}+\hat{b} P_{f}
$$

2 The constant (margin) does not necessarily depend only on the farm component of the retail good. It may also depend on existence of returns to scale, characteristics of market structure by exerting market power and some other factors such as mark-up changes, technological and other input cost changes. with $\hat{a}=\frac{1}{1-b}$ and $\hat{b}=\frac{1}{1-b}$.

If $\mathrm{P}_{\mathrm{r}}$ and $\mathrm{P}_{\mathrm{f}}$ are non-stationary, the tested relationship can be described as:

$$
\mathrm{P}_{\mathrm{r}, \mathrm{t}}=\hat{\mathrm{a}}+\hat{\mathrm{b}} \mathrm{P}_{\mathrm{f}, \mathrm{t}}+\varepsilon_{\mathrm{t}}
$$

where $\varepsilon_{\mathrm{t}}$ must be stationary if the above tested model is true in the long run. If the two prices are only linked by a constant absolute margin, then $\hat{b}$ has to be equal to unity $(\hat{b}=1)$. If $\hat{b} \neq 1$, one can assume that the margin consist of two components: a constant absolute amount (â) and a percentage amount $(\hat{b})$ of the retail price. In this case it can be assumed that intermediate traders and/or retailers charge a mark-up.

\section{Methodology}

To test the number of unit roots in each time data series, we applied the Augmented-Dickey-Fuller (ADF) Test (Dickey and Fuller 1979, 1981) and the Phillips-Perron (PP) Test (Phillips 1987, Phillips and Perron 1988). Since monthly data are used, seasonal unit roots can occur. The zero frequency unit root tests including 12 lags were used to capture seasonal structures.

Long-run vertical price relationships and reactions to deviations to the long run equilibrium in the Slovenian beef and pork markets are investigated using the multivariate Johansen (1988) ML co-integration approach, which allows testing for the presence of multiple co-integrating vectors and the speed of adjustment parameters. In the long run, we expect the equilibrium price relationships in the form of a co-integrating equilibrium relationship and a co-integrating vector to describe the speed of adjustment towards equilibrium. Co-integration refers to a linear combination of two or more integrated (i.e., difference-stationary) variables, which implies that stochastic trends of variables are linked over time, where there is also a link with the current deviation from the equilibrium relationship.

We use the vector autoregressive error correction model (VECM), which takes the following reduced form: 


$$
\Delta \mathrm{z}_{\mathrm{t}}=\Gamma_{1} \Delta \mathrm{z}_{\mathrm{t}}+\ldots+\Gamma_{\mathrm{k}-1} \Delta \mathrm{z}_{\mathrm{t}-\mathrm{k}+1}+\Pi \tilde{\mathrm{z}}_{\mathrm{t}-\mathrm{k}}+\Theta \mathrm{D}_{\mathrm{t}}+\varepsilon_{\mathrm{t}}
$$

where $z_{t}$ is a two-dimensional vector consisting of a retail and a farm-gate price, $\mathrm{z}_{\mathrm{t}}=\left(\mathrm{p}_{\mathrm{i}, \mathrm{t}} \mathrm{p}_{\mathrm{j}, \mathrm{t}}\right)^{\prime}, \tilde{\mathrm{z}}_{\mathrm{t}-\mathrm{k}}$ is defined as $\tilde{z}_{t-k}=\left(z_{t-k}^{\prime} 1\right)^{\prime}, D_{t}$ are centered seasonal dummies, and $\varepsilon_{\mathrm{t}}$ is the stochastic term $\left(\varepsilon_{\mathrm{t}}\right.$ are $\operatorname{niid}(0, \Sigma))$. The estimates of $\Gamma_{1}$ provide the shortrun and the estimates of $\Pi$ the long-run parameters. The latter matrix can be written as $\Pi=\alpha \tilde{\beta}^{\prime}=$ $\alpha\left(\beta^{\prime} \mu\right)$, where $\alpha$ represents the speed of adjustment to the long-run equilibrium and $\tilde{\beta}^{\prime} \tilde{z}_{t-k}$ is the matrix containing long-run coefficients and represents the co-integrating vectors. According to the theoretical framework, the constant $\mu$ is restricted to the co-integration space and represents the constant absolute component of the marketing and processing margin. The testing procedure follows Boswijk and Franses (1992) and Harris (1995). To test whether beef and pork markets are competitive, we carried out structural tests by imposing restrictions on the $\tilde{\beta}$ vector. A market is considered to be competitive if the long run coefficients of retail and farm gate prices are equal in absolute terms but with opposite signs. This means that we impose the following homogeneity constraint:

$$
\mathrm{H}_{0}: \beta \mathrm{p}_{\mathrm{i}}=-\beta \mathrm{p}_{\mathrm{j}}
$$

The restricted co-integration vector $\tilde{\beta}^{*}=\mathrm{H} \varphi$ is defined as:

$$
\tilde{\beta}^{*}=H \varphi=\left[\begin{array}{rr}
1 & 0 \\
-1 & 0 \\
0 & 1
\end{array}\right] \varphi, \varphi(2 \times 1)
$$

where $\mathrm{H}$ is the matrix containing homogeneity restrictions and unrestricted parameters and $\varphi$ is a matrix with unknown parameters. Linear restrictions are tested using a likelihood ratio test.

Weak exogeneity is tested to find out whether farm gate or retail prices adjust to the long run equilibrium after a price shock. The condition for a variable to be weakly exogenous for the long run parameters is that the $\alpha$ vector of the weakly exogenous variable equals zero. If a price variable $\left(\mathrm{p}_{\mathrm{j}, \mathrm{t}}\right)$ is found to be weakly exogenous, then a partial model is re-estimated:

$$
\begin{aligned}
\Delta \mathrm{p}_{\mathrm{i}, \mathrm{t}}= & \Gamma_{0} \Delta \mathrm{p}_{\mathrm{j}, \mathrm{t}}+\Gamma_{1} \mathrm{z}_{\mathrm{t}-1}+\ldots \\
& +\Gamma_{\mathrm{k}-1} \mathrm{z}_{\mathrm{t}-\mathrm{k}+1}+\Pi \tilde{\mathrm{z}}_{\mathrm{t}-1}+\Theta D_{\mathrm{t}}+\varepsilon_{\mathrm{t}}
\end{aligned}
$$

In this case $\tilde{\Pi}$ does not contain any information on the factor loadings $\alpha$ of the weakly exogenous variable $\mathrm{p}_{\mathrm{j}, \mathrm{t}}$, which leads very likely to improved statistical properties of the model (Johansen 1992).

The co-integration analysis and testing procedures are carried out using CATS (Hansen and Juselius 1995), that is a program that runs in RATS.

\section{Data}

Due to problems constructing data series of higher frequency (e.g. weekly) for Slovenia, monthly farm-gate and retail beef and pork prices are used in this analysis (January 1990 to August 2000). Farm-gate prices are represented by average purchase prices in Slovenian tolars (SIT) per $\mathrm{kg}$ of slaughter weight for beef (BF) and pork (PF), while a comparable set of retail prices of beef (BR) and pork (PR) is constructed from prices for meat cuts. ${ }^{3}$ Data on nominal prices are deflated using the Slovenian monthly consumer price index (CPI) with the base period in January 1990 to obtain a series of real prices. Henceforth prices refer to real prices. The deflation procedure neither causes changes in the farm-to-retail price ratio, nor results in a different price transmission model. The source of the monthly commodity price series and CPI

\footnotetext{
3 The average slaughter conversion factor of 0.54 for beef and 0.72 for pork were used when converting farmgate prices from a live weight in a slaughter weight. The retail price of beef (BR) is constructed as the arithmetic average of retail prices for "young boned beef" and "young unboned beef'. Therefore, our retail beef price consists only of fresh meats. The retail price for pork (PR) is constructed as the weighted average of retail prices of "boned pork" (weighted by 0.45), "pork without bones" (0.4), "ham, no fat no skin" (0.05), "smoked bacon" (0.05) and "rolled ham" (0.05). Note that beef and pork are sold in a wide variety of products at the retail level. This is important to note for cross-country and across market comparisons.
} 
Vol. 14 (2005): 236-249.

data is the Statistical Office of the Republic of Slovenia (SORS).

Price data analysis showed erratic price movements in the years 1991-1992 (Fig. 1). The retail pork prices per $\mathrm{kg}$ are higher than the retail beef prices, while the farm-gate beef prices are higher than the farm-gate pork prices. ${ }^{4}$ Consequently, the processing and marketing margin in the pork market is greater than in the beef market. Lower farmgate prices for pork compared to beef can be explained by supply side factors, especially better cost efficiency in the conversion of feed into pork than into beef. Higher pork retail prices compared to beef retail prices can be explained by demand side factors, especially consumer preference for pork in contrast to beef. ${ }^{5}$ In general the farm-gate beef and pork prices are more stable than the retail beef and pork prices. The period 1990-1992 includes a shock, which followed the secession from the former Yugoslavia, when farm-gate beef and pork prices and retail beef and pork prices sharply increased. Price instability in the pork market was much lower in the period 1994-2000 than in the period 1990-1993.

The slightly lower volatility of the pork margin could indicate more long-term arrangements throughout the pork chain. Higher stability of the farm-gate pork prices after 1993 could be explained by a rather high market share of hogs on

4 This holds also when only fresh beef and pork prices are considered at the retail level.

5 According to the Slovenian meat market balances, per capita pork consumption was at least 50 percent greater than beef consumption during the 1990s. Between 1992 and 1999, annual per capita meat consumption increased from $77.8 \mathrm{~kg}$ in 1992 to $92.3 \mathrm{~kg}$ in 1999 . The annual per capita beef consumption increased from $22.6 \mathrm{~kg}$ in 1992 to $28.3 \mathrm{~kg}$ in 1993 , but declined steadily afterwards to 22.1 $\mathrm{kg}$ in 1999 . The annual per capita pork consumption increased from $32.2 \mathrm{~kg}$ in 1992 to $41.5 \mathrm{~kg}$ in 1999 . In 1992 , beef $(29.1 \%)$ and pork $(41.4 \%)$ represented $70.5 \%$ of meat consumption. The share of other meats was $29.5 \%(22 \%$ poultry, $0.2 \%$ sheep and goats, $1.3 \%$ horse meat, and $6 \%$ meat of offal). In 1999, the structure of meat consumption in Slovenia was the following: $69 \%$ beef $(24 \%)$ and pork ( $45 \%)$, and $31 \%$ other meats $(26.1 \%$ poultry, $0.6 \%$ sheep and goats, $0.3 \%$ horse meat, and $4 \%$ meat of offal).
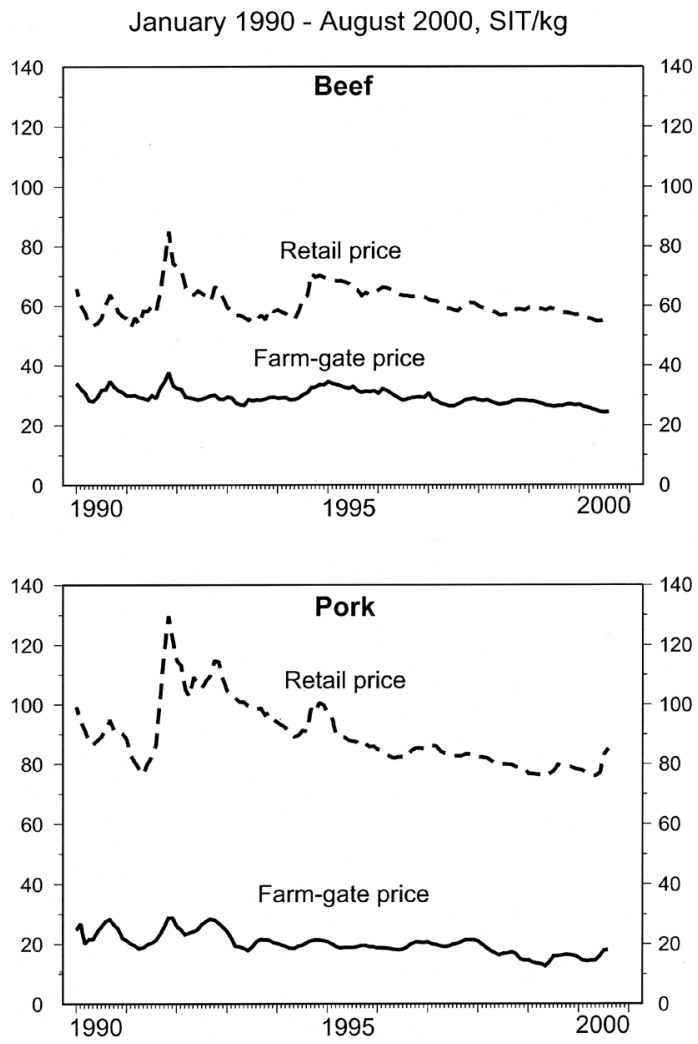

Source: Own calculations on the basis of data from the Statistical Office of the Republic of Slovenia.

Fig. 1. Monthly real meat prices in Slovenia.

large-scale commercial farms, which are likely to have a better and more successful bargaining position with slaughterhouses for delivery of hogs at rather stable prices. Finally, this difference could also be due to differences in government trade and intervention policies, and due to an increase in the volatility of beef retail and farm-gate prices in response to the BSE crisis in some of the EU countries.

\section{Empirical results}

In this chapter the results of the unit root tests, cointegration analyses, structural as well as weak 
Bojnec, $\check{S}$. \& Peter, G. Vertical market integration and competition

Table 1. Results of unit root tests, January 1990-August 2000.

\begin{tabular}{lcccc}
\hline Tests & $\begin{array}{c}\text { Beef } \\
\text { retail price }\end{array}$ & $\begin{array}{c}\text { Beef } \\
\text { farm-gate price }\end{array}$ & $\begin{array}{c}\text { Pork } \\
\text { retail price }\end{array}$ & $\begin{array}{c}\text { Pork } \\
\text { farm-gate price }\end{array}$ \\
\hline ADF test with trend & $-2.82^{*}$ & -1.60 & $-3.19^{*}$ & $-3.32^{*}$ \\
ADF test with constant & -2.38 & -0.62 & -1.54 & -1.39 \\
PP test with trend & $-3.17^{*}$ & $-3.47^{* *}$ & -2.86 & $-3.63^{* *}$ \\
PP test with constant & $-3.13^{* *}$ & $-2.78^{*}$ & -2.30 & -2.50 \\
\hline
\end{tabular}

* Denotes a 0.90 significance level.

** Denotes a 0.95 significance level.

Note: To capture seasonal structure the models include 12 additional lags in Augmented-Dickey-Fuller (ADF) test. For the Phillips-Perron (PP) test we applied the Newey-West correction (4 truncation lags). Based on Fuller (1976), the critical values at a 0.95 (0.90) significance level for ADF and PP tests with trend are $-3.45(-3.15)$ and the critical values for ADF and PP tests with constant are $-2.89(-2.58)$.

exogeneity tests are presented. Since the period 1990-93 was influenced by strong shocks, we analysed two different periods. ${ }^{6}$ First, we estimated the long run price transmission for the total period from January 1990 to August 2000 and in a second step, data of the first four years were omitted to avoid the models being strongly influenced by high volatility in the years 1990-1993. Therefore, we additionally estimated beef and pork models for the period 1994-2000.

Thus, we started by investigating the order in which the four price series are individually integrated. By applying zero frequency ADF unit root tests including 12 lags and the PP test with four truncation lags to the January 1990-August 2000 series we found - on a 0.90 significance level - that (using unit root tests with trend) 7 out of 8 tests indicate the time series to be trend stationary (Table 1). On a 0.95 significance level the two farmgate prices are seen as $\mathrm{I}(0)$, i.e. trend-stationary variables.

\footnotetext{
6 We started our analysis with the January 1990-August 2000 period as a whole to empirically clarify whether and how market intervention and break away from traditional markets cause the results. It was confirmed that the result is biased to trade disintegration shock and government intervention measures in the initial period. So the results for the second sub-period January 1994-August 2000 are presented in more detail, while the result for the January 1990-August 2000 period as a whole is only provided for a certain comparison.
}

Applying the same tests to the period January 1994-August 2000 all price series are found to be non-stationary on a 0.95 significance level (Table 2). Only the series PF is found to be trend-stationary on a 0.90 significance level. Based on these results and a further unit root test for the first differences all four series in the period January 1994August 2000 are considered as I(1) variables.

Since there is a near equivalence between trend-stationary and difference-stationary processes it is difficult to distinguish between them in finite samples. Unit root tests tend to over-reject the null hypothesis when it is true (poor size property) and to under-reject when it is false (poor power property). Thus, it is not possible to state that a variable is stationary or non-stationary, but to state that a certain finite sample exhibits stationary or non-stationary attributes (Harris 1995). This was the reason that we also applied co-integration analysis to the January 1990-August 2000 period, although the unit root tests for that period suggested most of the variables to be trend-stationary.

The number of agents in the pork and beef markets does not necessarily imply a stronger probability of finding price transmission in the market with a higher number of agents (the beef market in our case). Namely, price transmission can be influenced by some other factors such as government policies, bargaining and different contractual arrangements. To test vertical price transmission in the beef and pork chains, respectively, the co-integration analysis is carried out within the same vertical meat market chain (i.e., separately 
Vol. 14 (2005): 236-249.

Table 2. Results of unit root tests, January 1994-August 2000.

\begin{tabular}{lcccc}
\hline Tests & $\begin{array}{c}\text { Beef } \\
\text { retail price }\end{array}$ & $\begin{array}{c}\text { Beef } \\
\text { farm-gate price }\end{array}$ & $\begin{array}{c}\text { Pork } \\
\text { retail price }\end{array}$ & $\begin{array}{c}\text { Pork } \\
\text { farm-gate price }\end{array}$ \\
\hline ADF test with trend & -1.76 & -2.15 & -1.53 & $-3.42^{*}$ \\
ADF test with constant & -0.54 & -0.91 & -1.66 & -2.07 \\
PP test with trend & -2.80 & -2.79 & -1.73 & -2.06 \\
PP test with constant & -1.41 & -0.80 & -1.71 & -1.76 \\
\hline
\end{tabular}

* Denotes a 0.90 significance level.

Note: To capture seasonal structure the models include 12 additional lags in Augmented-Dickey-Fuller (ADF) test. For the Phillips-Perron (PP) test we applied the Newey-West correction (3 truncation lags). Based on Fuller (1976) the critical values at a 0.95 (0.90) significance level for ADF and PP tests with trend are $-3.45(-3.15)$ and the critical values for ADF and PP tests with constant are $-2.89(-2.58)$.

for beef and for pork) evaluating the size and relationship between farm-gate price on one side and retail-price on the other.

The results of the co-integration analysis are presented in Tables 3, 4 and 5. Based on the trace statistics, the results of the rank (r) test indicate one co-integrating vector in the beef market in both periods January 1990-August 2000 and January 1994-August 2000 and one in the pork market in the period August 1994-August 2000. In the pork model for the period January 1990-August 2000 no co-integration relationship was found. The test for the unit roots within the multivariate Johansen ML approach suggests that all data series used in our models with one co-integrating vector are non-stationary. This holds also for the beef price series in the January 1990-August 2000 model.

As can be seen from the test results on the residuals, the model selection was mainly based on two out of four tests applied. The co-integration vector is presented in a normalized form, i.e. in such a way that the first element of each model (e.g. the coefficient of the beef retail price BR in the first row) is set equal to unity. The normalized coefficients are presented in Table 3, columns five and six, respectively.

Based on the estimated coefficients in Table 3, the long run price relationships (ECT) for the different models are:

$$
\begin{aligned}
& \text { Beef }(1990-2000) \\
& \text { ECT }=\text { BR }-1.403 * \mathrm{BF}-17.532 \\
& \text { Beef }(1994-2000) \\
& \text { ECT }=\text { BR }-1.541 * \mathrm{BF}-15.933
\end{aligned}
$$

$$
\begin{aligned}
& \text { Pork (1994-2000) } \\
& \text { ECT }=\text { PR }-1.234 * \mathrm{PF}-58.985
\end{aligned}
$$

For pork, we did not find any co-integration vector in the period January 1990-August 2000. This suggests an absence of long run price relationship between pork retail and farm gate prices during this period.

In the next step we analyse whether the price changes are transmitted completely from one level to another and whether price changes are mainly caused by supply side or demand side factors. We apply structural and weak exogeneity tests imposing homogeneity restrictions on the $\beta$ coefficients and zero restrictions on the $\alpha$ coefficients. Table 4 summarizes the results of the different tests. Column 1 describes the model, while Column 2 presents the tested hypotheses. First, structural tests are carried out to identify the co-integration space (Row 1). In Rows 2 and 3, the structural tests are combined with weak exogeneity tests. According to Harris (1995), tests on weak exogeneity can only be interpreted with identified structural $(\beta)$ parameters. Additionally, the results of weak exogeneity tests are also reported (Rows 4 and 5). Columns 3 and 4 contain the respective Likelihood ratio (LR) test statistics and significance levels (P-values).

To test whether markets are competitive or non-competitive, structural tests have been carried out. The results are presented in Table 4, Rows 1, 2 and 3 for each model. As can be seen only in the case of the pork model for the period August 1994-August 2000, the restricted model is not significantly different from the unrestricted model. This suggests that the margin in the pork model is 


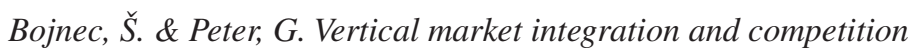

Table 3. Results of co-integration analysis.

\begin{tabular}{|c|c|c|c|c|c|c|c|c|c|}
\hline \multirow{3}{*}{$\begin{array}{c}\text { Model } \\
\mathrm{p}_{\mathrm{i}}-\mathrm{p}_{\mathrm{j}}\end{array}$} & \multirow[t]{3}{*}{ Lags } & \multirow{3}{*}{$\begin{array}{l}\text { Seasonal } \\
\text { dummies }\end{array}$} & \multirow{3}{*}{$\begin{array}{c}\text { Trace } \\
\text { statistics }\end{array}$} & \multicolumn{2}{|c|}{ Normalised } & \multicolumn{4}{|c|}{ Tests on the residuals } \\
\hline & & & & \multirow[t]{2}{*}{$\beta \mathrm{p}_{\mathrm{j}}$} & \multirow[t]{2}{*}{ Constant } & \multirow{2}{*}{$\begin{array}{c}\text { Ljung } \\
\text { Box test } \\
\text { (LB) } \\
\text { P-value }\end{array}$} & \multicolumn{2}{|c|}{$\begin{array}{c}\text { Lagrange } \\
\text { Multiplier test }\end{array}$} & \multirow{2}{*}{$\begin{array}{c}\text { Normality } \\
\text { test } \\
\text { P-value }\end{array}$} \\
\hline & & & & & & & $\begin{array}{l}\text { LM(1) } \\
\text { P-value }\end{array}$ & $\begin{array}{l}\text { LM(4) } \\
\text { P-value }\end{array}$ & \\
\hline $\begin{array}{l}\text { Beef } \\
1990-2000\end{array}$ & 11 & No & $\begin{array}{l}23.51 * * \\
3.79\end{array}$ & -1.403 & -17.532 & 0.10 & 0.73 & 0.03 & 0.00 \\
\hline $\begin{array}{l}\text { Beef } \\
1994-2000\end{array}$ & 10 & No & $\begin{array}{l}25.63 * * * \\
3.25\end{array}$ & -1.541 & -15.933 & 0.00 & 0.55 & 0.77 & 0.02 \\
\hline $\begin{array}{l}\text { Beef }^{\mathrm{a}} \\
1994-2000\end{array}$ & 10 & No & - & -1.547 & -15.868 & 0.37 & 0.61 & 0.77 & 0.49 \\
\hline $\begin{array}{l}\text { Pork } \\
\text { 1990-2000 }\end{array}$ & \multicolumn{9}{|c|}{ No co-integration } \\
\hline $\begin{array}{l}\text { Pork } \\
1994-2000\end{array}$ & 12 & Yes & $\begin{array}{l}22.20^{* *} \\
6.61\end{array}$ & -1.234 & -58.985 & 0.00 & 0.26 & 0.67 & 0.00 \\
\hline Pork $^{\mathrm{a}}$ & 12 & Yes & - & -1.120 & -61.154 & 0.00 & 0.49 & 0.76 & 0.00 \\
\hline
\end{tabular}

$\mathrm{p}_{\mathrm{i}}$ - Retail price $\mathrm{p}_{\mathrm{j}}$ - Farm gate price ${ }^{\mathrm{a}}$ Partial model

** Denotes a 0.95 significance level (trace statistics) $* * *$ Denotes a 0.99 significance level (trace statistics)

Note: Table reports only the trace test since it shows more robustness to skewness and excess kurtosis in the residuals than the maximal eigenvalue test (Cheung and Lai 1993). The beef model is estimated for the periods January 1990August 2000 and January 1994-August 2000, respectively. The pork model is estimated for the periods January 1990August 2000 and August 1994-August 2000, respectively.

Table 4. Results of structural and weak exogeneity tests.

\begin{tabular}{llcc}
\hline Model & Tested hypotheses & Likelihood ratio test statistics & P-value \\
\hline Beef & $\tilde{\beta}=\tilde{\beta}^{*}=\left[\begin{array}{rrr}1 & -1 & 0 \\
0 & 0 & 1\end{array}\right]$ & $\chi^{2}(1)=3.89$ & 0.05 \\
January 1990-August 2000 & $\alpha_{\mathrm{BR}}=0 \wedge \tilde{\beta}=\tilde{\beta}^{*}$ & $\chi^{2}(2)=17.36$ & 0.00 \\
& $\alpha_{\mathrm{BF}}=0 \wedge \tilde{\beta}=\tilde{\beta}^{*}$ & $\chi^{2}(2)=10.12$ & 0.01 \\
& $\alpha_{\mathrm{BR}}=0$ & $\chi^{2}(1)=15.78$ & 0.00 \\
& $\alpha_{\mathrm{BF}}=0$ & $\chi^{2}(1)=6.30$ & 0.01 \\
& $\tilde{\beta}=\tilde{\beta}^{*}=\left[\begin{array}{rrr}1 & -1 & 0 \\
0 & 0 & 1\end{array}\right]$ & $\chi^{2}(1)=9.30$ & 0.00 \\
Beef & $\alpha_{\mathrm{BR}}=0 \wedge \tilde{\beta}=\tilde{\beta}^{*}$ & & 0.00 \\
January 1994-August 2000 & $\alpha_{\mathrm{BF}}=0 \wedge \tilde{\beta}=\tilde{\beta}^{*}$ & $\chi^{2}(2)=21.17$ & 0.00 \\
& $\alpha_{\mathrm{BR}}=0$ & $\chi^{2}(2)=11.16$ & 0.00 \\
& $\alpha_{\mathrm{BF}}=0$ & $\chi^{2}(1)=18.37$ & 0.63 \\
Pork & $\tilde{\beta}=\tilde{\beta}^{*}=\left[\begin{array}{rrr}1 & -1 & 0 \\
0 & 0 & 1\end{array}\right]$ & $\chi^{2}(1)=0.23$ & 0.35 \\
August 1994-August 2000 & $\chi_{\mathrm{PR}}=0 \wedge \tilde{\beta}=\tilde{\beta}^{*}$ & $\chi^{2}(1)=0.88$ & 0.00 \\
& $\alpha_{\mathrm{PF}}=0 \wedge \tilde{\beta}=\tilde{\beta}^{*}$ & $\chi^{2}(2)=13.16$ & 0.63 \\
& $\alpha_{\mathrm{PR}}=0$ & $\chi^{2}(2)=0.92$ & 0.01 \\
& $\alpha_{\mathrm{PF}}=0$ & $\chi^{2}(1)=5.95$ & 0.44 \\
\hline
\end{tabular}

$\mathrm{BR}$ - Beef retail price. $\mathrm{BF}$ - Beef farm-gate price. $\mathrm{PR}$ - Pork retail price. $\mathrm{PF}$ - Pork farm-gate price.

Note: For each model the first row presents structural tests, the second and third rows structural tests together with tests on weak exogeneity, and the fourth and fifth rows tests on weak exogeneity. 
Vol. 14 (2005): 236-249.

more likely to be a constant absolute margin, while the margin in the beef market is a mixture of a constant and a percentage margin.

One important issue of empirical and policy concern in price transmission models is identification of the source of the changes occurring in the food (i.e. meat) chain and whether the changes in the prices between stages depend on whether the changes occur on the supply side ("pass-through" price transmission) or are induced by demand side factors ("pass-back" price transmission). The results of the weak exogeneity tests indicate that in the 1994-2000 models the farm-gate prices (BF and $\mathrm{PF}$ ) are weakly exogenous and the retail prices (BR and PR) react to changes in the farm-gate prices. This means that the price changes were mainly induced by producer side factors as only $\mathrm{BR}$ and PR respond to deviations from the long run equilibrium. Due to this, these models were reestimated as partial models where the farm gate price entered the model as weakly exogenous variable, which improves the stochastic properties of the model (see Table 3).

The long run price relation between retail and farm gate prices for the period 1994-2000 can be described as:

$$
\begin{aligned}
& \mathrm{BR}=15.9+1.5 * \mathrm{BF} \\
& \mathrm{PR}=59.0+1.2 * \mathrm{PF} .
\end{aligned}
$$

Re-estimated as partial model the results change only slightly:

$$
\begin{aligned}
& \mathrm{BR}=15.9+1.5 * \mathrm{BF} \\
& \mathrm{PR}=61.2+1.1 * \mathrm{PF} .
\end{aligned}
$$

For the beef market (January 1990-August 2000) it is not possible to identify whether the price changes are mainly caused by supply or demand side factors.

Based on these results the long run margin can be computed along the theoretical background. Price transmission in the beef sector in the period January 1990-August 2000 and long run margin equation can be described as:

$$
\begin{aligned}
& \hat{b}=\frac{1}{1-b}=1.403 \quad \Rightarrow b=0.287 \\
& \hat{a}=\frac{a}{1-b}=17.532 \quad \Rightarrow a=12.496 \\
& \operatorname{Margin}_{\text {Beef }(1990-2000)}=12.496+0.287 * B R
\end{aligned}
$$

which clearly indicates the mark-up processing and marketing margin in the beef sector.

Price transmission in the beef sector in the period January 1994-August 2000 and long run margin equation can be described as:

$$
\begin{aligned}
& \hat{b}=\frac{1}{1-b}=1.547 \quad \Rightarrow b=0.354 \\
& \hat{a}=\frac{a}{1-b}=15.868 \quad \Rightarrow a=10.257 \\
& \operatorname{Margin}_{\text {Beef }(1994-2000)}=10.257+0.354 * B R,
\end{aligned}
$$

which clearly reveals the mark-up processing and marketing margin in the beef sector.

Since the structural test has shown that $\hat{b}$ does not statistically differ from unity, price transmission in the pork sector in the period August 1994August 2000 and long run margin equation can be described as:

$$
\begin{aligned}
& \text { Margin }_{\text {Pork (1994-2000) }}=63.279 \\
& \text { PR = 63.279 + PF, }
\end{aligned}
$$

which indicates a competitive processing and marketing margin in the pork sector. The results suggest an absence of oligopoly or oligopsony power in the pork market, where large-scale commercial hog farms are the main supplier of hogs to slaughterhouses. On the other hand, it also suggests market power by slaughterhouses and traders in the beef market, where more dispersed individual or family farms are the main supplier of cattle to the slaughterhouses.

Table 5 presents the $\alpha$ coefficients for the speed of adjustment of retail and farm-gate prices to the long-run equilibrium. Except in the case of $\Delta \mathrm{PF}$, the $\alpha$ coefficient is of the negative sign. As can be seen from the $\alpha$ coefficient, retail prices reacted more intensively to unanticipated shocks than farm-gate prices. The responses in the beef market were faster than in the pork market. The greatest magnitude in the $\alpha$ coefficient is found in the case of $\triangle \mathrm{BR}$ for the 1994-2000 model. It accounted for -0.634 , suggesting the intensive and significant adjustment in retail beef price to unanticipated shocks in farm-gate beef price away from the longrun equilibrium. The $\alpha$ coefficient associated with farm-gate prices are less than with retail prices. Except for the $\triangle \mathrm{BF}$ in the January 1990-August 
Bojnec, $\breve{S}$. \& Peter, G. Vertical market integration and competition

Table 5. Factor loading matrix.

\begin{tabular}{lccc}
\hline Model & Variable & $\alpha$ & t value \\
\hline Beef & $\Delta \mathrm{BR}$ & -0.371 & -4.610 \\
January 1990-August 2000 & $\Delta \mathrm{BF}$ & -0.094 & -2.826 \\
Beef & $\Delta \mathrm{BR}$ & -0.634 & -5.012 \\
January 1994-August 2000 & $\Delta \mathrm{BF}$ & -0.039 & -0.515 \\
Pork & $\Delta \mathrm{PR}$ & -0.232 & -3.696 \\
August 1994-August & $\Delta \mathrm{PF}$ & 0.007 & 0.205 \\
Pork ${ }^{\mathrm{a}, \mathrm{b}}$ & $\Delta \mathrm{PR}$ & -0.237 & -4.076 \\
August 1994-August 2000, & & & \\
\hline
\end{tabular}

$\mathrm{BR}$ - Beef retail price. $\mathrm{BF}$ - Beef farm-gate price. PR - Pork retail price. PF - Pork farm-gate price.

Note: ${ }^{\text {a }}$ Partial model. ${ }^{\mathrm{b}}$ Restricted model (homogeneity restrictions for $\beta$ parameter).

2000 model, the $\alpha$ coefficient associated with farm-gate prices was not found to be statistically significant. As the speed of adjustment coefficients and the structural tests indicate, price reactions in the beef market are faster and more profound, but are not completely transmitted, while price adjustments in the pork market are slower but completely transmitted to consumers.

\section{Conclusion and policy implications}

The paper has explored issues arising from linkages between agriculture, processing, and marketing in the meat chain during the period of economic transition in Slovenia. More specifically, the paper has analysed the natures of vertical market integration and price transmission on the source of the changes of the margin and degree of market competition on evaluating the outcomes of policy reforms and the distribution of welfare changes in the meat chain. One of the most striking findings of the analysis for Slovenia, but with broader policy importance, is that protected markets may perform as competitive markets, but are less likely to be efficient markets in terms of the size of the margin. It is more likely, as it is confirmed for the Slovenian meat markets, that a processing and marketing margin for a provided similar quality of marketing service is greater than in more perfectly competitive markets in market economies. The processing and marketing margin in the Slovenian pork market is greater than in the beef market owing to the higher retail pork price compared to the lower retail beef price on the one hand, and due to the lower farm-gate pork price compared to the higher farm-gate beef price on the other. The development in processing and marketing margin in the pork market indicates an adjustment to more competitive markets, whereas at the cattle-beef marketing chain, farm-gate cattle prices experience a decline at more stable retail beef prices.

The results of the vertical market integration and price competitiveness using the multivariate Johansen ML co-integration approach suggest, except for the pork model in the period January 1990-August 2000, a long-run price relationship in both the beef and pork markets. Co-integration results indicate that there has been long-run vertical market integration with price transmission between the farm-gate beef and the retail beef prices and in the pork market since 1994. The results of the weak exogeneity tests identify the farm-gate beef and pork prices as weakly exogenous, while the retail beef and pork prices react to changes in the farm-gate beef and pork prices. The passthrough price transmission changes between stages in the meat chain depend on the changes occurring on the supply side. Therefore, efficiency improvements and lower costs arising from producer side 
Vol. 14 (2005): 236-249.

factors, particularly in meat processing and marketing, have been crucial for the retail price changes in the Slovenian meat market.

The structural test imposing the restrictions implied by competition indicates that processors and traders in the beef market charged a mark-up of the retail price for beef plus an absolute constant margin. This indicates the existence of market power in the beef processing and marketing in the long run. With more-than-proportional changes in prices at successive stages, there is an impact on the welfare distribution of cattle farmers and particularly from consumers to beef processors and traders. For pork, the empirical results indicate that even in an externally isolated and ad hoc regulated market, the processors and traders charged a constant absolute margin. In an absence of open external trade and limited foreign price transmission on domestic pork markets, this suggests absence of internal selling (oligopoly) market power and competitive processing and marketing margin formation. This smoother internal input price and margin transmission in the pork processing and marketing chain seem to be due to the rather vertically integrated pork market in Slovenia with also weaken buying (oligopsony) power. Contractual arrangements between farms and slaughterhouses seem to work better in the pork market, where large-scale commercial farms are the main supplier of pigs, while small-scale farms predominantly produce pork for home consumption. Small-scale farms mainly produce cattle, and unlike pork, it is marketed to the slaughterhouses.

The co-integration results clearly suggest that even in a situation of an externally isolated and internally regulated meat market, as it was the case in Slovenia during the 1990s, the meat market may behave like a competitive market. However, it is less likely that the existent market structures and policy-induced transfers are sustainable. As in some other CEE transition countries (e.g. Hungary and Poland), functioning agricultural and food markets have developed quickly. Further adjustments, restructuring, and cost efficiency improvements to reduce farm, processing and market inefficiencies towards more competitive markets are an ongoing process. This holds particularly after the EU accession inducing deeper processing and marketing deregulations in the enlarged EU markets. This process is similar to other EU countries with an increasing presence of supermarkets as consumer market outlets.

Acknowledgements. This article was prepared during the authors' stay at the Institute of Agricultural Development in Central and Eastern Europe (IAMO) in Halle (Saale), Germany. An earlier version of this paper was presented in Leuven in Belgium, Warsaw in Poland, and in Zaragoza in Spain. The authors gratefully acknowledge helpful comments from participants at the meetings, Adusei Jumah, José M. Gil, Karl Ortner and two anonymous referees. Furthermore the authors are grateful to the Slovenian Statistical Office for providing the data on prices and Miro Rednak for explanation of supplementary data on meat market balances in Slovenia. The editorial work by Dina Führmann is highly appreciated.

\section{References}

Baldwin, R.E., Francois, J.E. \& Portes, R. 1997. EU enlargement: small costs for the West, big gains for the East. Economic Policy 24: 125-176.

Bojnec, Š. 1999. The competitiveness of Slovenian farms and food processing activities. Agrarwirtschaft 48: 295303.

Bojnec, Š. \& Swinnen, J.F.M. 1997. The pattern of agricultural price distortions in Central and Eastern Europe. Food Policy 22: 289-306.

Boswijk, H.P. \& Franses, P.H. 1992. Dynamic specification and co-integration. Oxford Bulletin of Economics and Statistics 54: 369-381.

CCS 2002. Registered slaughtering of cattle and pigs in Slovenia in 1997 and 2000. Ljubljana: Chamber of Commerce of Slovenia. $40 \mathrm{p}$.

Cheung, Y.-W. \& Lai, K.S. 1993. Finite-sample size of Johansen's likelihood ratio test for co-integration. Oxford Bulletin of Economics and Statistics 55: 313-328.

Dickey, D.A. \& Fuller, W.A. 1979. Distribution of the estimators for autoregressive time series with a unit root. Journal of the American Statistical Association 74: 427-431.

Dickey, D.A. \& Fuller, W.A. 1981. Likelihood ratio statistics for autoregressive time series with a unit root. Econometrica 49: 1057-1072.

Eiteljörge, U. \& Hartmann, M. 1999. Central and Eastern European food chain competitiveness. In: The European agro-food system and the challenge of global competition. Rome: The International Food and Agribusiness Management Association - ISMEA. p. 187-224. 


\section{AGRICULTURAL AND FOOD SCIENCE}

Bojnec, $\check{S}$. \& Peter, G. Vertical market integration and competition

European Commission 2004. The future of rural areas in an enlarged EU: Perspectives for the new member states in Central and Eastern Europe and Bulgaria and Romania. Luxembourg: Office for Publications of the European Communities. $238 \mathrm{p}$.

Fuller, W.A. 1976. Introduction to statistical time series. New York: Wiley. $470 \mathrm{p}$.

Hansen, H. \& Juselius, K. 1995. CATS in RATS: co-integration analysis of time series. Evanston, IL: Estima. 88 p.

Harris, R.I.D. 1995. Using co-integration analysis in econometric modelling. Harvester Wheatsheaf: Prentice Hall. $195 \mathrm{p}$.

Ivanova, N., Lingard, J., Buckwell, A. \& Burrell, A. 1995. Impact of changes in agricultural policy on the agro-food chain in Bulgaria. European Review of Agricultural Economics 22: 354-371.

Johansen, S. 1988. Statistical analysis of cointegrating vectors. Journal of Economic Dynamics and Control 12: 231-254.

Johansen, S. 1992. Co-integration in partial systems and the efficiency of single equation analysis. Journal of Econometrics 52: 389-402.

Jumah, A. 2000. The long run, market power and retail pricing. Economics Series No. 78. Vienna: Institute for Advanced Studies. $18 \mathrm{p}$.

MAFF 2002. Poročilo o stanju kmetijstva, gozdarstva in živilstva v letu 2000 (Report on the situation in agriculture, forestry, and food in 2000). Ljubljana: Ministry of Agriculture, Forestry and Food. 162 p.
OECD 1998. Impediments to efficiency in the agro-food chain in Bulgaria, Romania, and Slovenia. Agricultural Policy Papers 1998-02. Paris: Organisation for Economic Cooperation and Development. 50 p.

OECD 2001. Review of agricultural policies - Slovenia. Paris: Organisation for Economic Cooperation and Development, Centre for co-operation with non-members. $184 \mathrm{p}$.

Phillips, P.C.B. 1987. Time series regression with a unit root. Econometrica 55: 277-301.

Phillips, P.C.B. \& Perron, P. 1988. Testing for a unit root in time series regression. Biometrica 75: 335-346.

SORS 1997. Farm structure survey. Ljubljana: Statistical Office of the Republic of Slovenia. $38 \mathrm{p}$.

SORS 2002. Agricultural census - Slovenia 2000. Ljubljana: Statistical Office of the Republic of Slovenia. $256 \mathrm{p}$.

Stiglitz, J.E. 1987. The causes and consequences of the dependence of quality on price. Journal of Economic Literature 25: 1-48.

Swinnen, J.F.M. 1998. Economic transition and the distribution of policy rents: the case of the wheat-flour-bread chain in Bulgaria. European Review of Agricultural Economics 25: 243-258.

Tangermann, S. \& Banse, M. 2000. Central and Eastern European agriculture in an expanding European Union. Wallingford: CABI Publishing. 210 p.

Tomek, W.G. \& Robinson, K.L. 1995. Agricultural product prices. Ithaca: Cornell University Press. 360 p. 


\section{AGRICULTURAL AND FOOD SCIENCE}

Appendix. Structure of cattle and hog farms and meat processing in Slovenia.

Table A1. Structure of cattle and hog farms in Slovenia.

\begin{tabular}{|c|c|c|c|c|c|c|}
\hline & $\begin{array}{c}\text { Number of } \\
\text { farms }\end{array}$ & $\begin{array}{c}1997 \\
\text { Number of } \\
\text { heads }\end{array}$ & $\begin{array}{c}\text { Average size } \\
\text { (heads per farm) }\end{array}$ & $\begin{array}{l}\text { Number of } \\
\text { farms }\end{array}$ & $\begin{array}{c}2000 \\
\text { Number of } \\
\text { heads }\end{array}$ & $\begin{array}{c}\text { Average size } \\
\text { (heads per farm) }\end{array}$ \\
\hline \multicolumn{7}{|l|}{ Cattle } \\
\hline Family farms & 63,934 & 469,688 & 7.4 & 56,070 & 483,511 & 8.6 \\
\hline Agricultural enterprises & 44 & 27,163 & 617.3 & 27 & 16,035 & 593.9 \\
\hline Total cattle farms & 63,978 & 496,851 & 7.8 & 56,097 & 499,546 & 8.9 \\
\hline \multicolumn{7}{|l|}{ Hogs } \\
\hline Family farms & 50,522 & 364,965 & 7.2 & 44,606 & 390,155 & 8.8 \\
\hline Agricultural enterprises & 29 & 236,225 & $8,145.7$ & 17 & 211,798 & $12,458.7$ \\
\hline Total hog farms & 50,551 & 601,190 & 11.9 & 44,623 & 601,953 & 13.5 \\
\hline
\end{tabular}

Source: Authors' calculations on the basis of the data from the Statistical Office of the Republic of Slovenia SORS (1997) and SORS (2002).

Table A2. Structure of meat processing in Slovenia.

\begin{tabular}{|c|c|c|c|c|}
\hline & \multicolumn{2}{|c|}{$\begin{array}{c}1997 \\
\text { Registered slaughterhouses }\end{array}$} & \multicolumn{2}{|c|}{$\begin{array}{c}2000 \\
\text { Registered slaughterhouses }\end{array}$} \\
\hline & Beef & Pork & Beef & Pork \\
\hline Number of firms & 35 & 11 & 34 & 11 \\
\hline Production $^{\mathrm{a}}$ & $33,712.7$ & 271.0 & $34,193.8$ & 331.9 \\
\hline Four largest producers (\%) & 36.7 & 64.2 & 37.0 & 61.9 \\
\hline Six largest producers $(\%)$ & 48.0 & 89.3 & 50.3 & 78.6 \\
\hline
\end{tabular}

${ }^{a}$ Number of slaughtered heads (in thousands).

Note: Total number of meat processing enterprises (NACE-151) in Slovenia was 49 (3,233 employees) in 1997 and 59 (4,751 employees) in 2000.

Sources: CCS (2002) and MAFF (2002). 